\title{
of Law and Religion
}

Volume XV

Numbers 1 and 2

2000-2001
Guest Editor's Introduction

\section{Articles}

Fatwa Concerning the United States Supreme Courtroom Frieze

The Legal Status of Women:

The Journey Toward Equality

Muslim Women's Rights in the Global Village:

Challenges and Opportunities

A Student Note:

Religious Marriage Contracts: Judicial Enforcement of Mahr Agreements in American Courts

Law, Religion and the Prophetic Method of Social Change

Principles of Islamic Interpersonal Conflict Intervention:

A Search within Islam and Western Literature

The Dilemma of Islamic Rights Schemes

A Framework for Nonviolence and Peacebuilding in Islam

Secrecy, Guilt by Association, and the Terrorist Profile

David Cole

\section{Review Essays}

Modem Law and Arab Societies in Recent French-Speaking Literature

Baudouin Dupret

The Study of Islamic Law in Germany:

A Review of Recent Books on Islamic Law

Spanish Research on Islamic Law, 1990-1999
Taha Jaber al-Alwani

Jawdat Said

Mohammed Abu-Nimer

Azizah Yahia al-Hibri

Sandra Day $O^{\prime}$ Connor

Azizah Yahia al-Hibri

Ghada G. Qaisi

Amr Abdalla

Ebrahim Moosa 


\section{Sponsored by: Hamline University School of Law \\ Published by: $\quad$ Hamline University School of Law ISSN: 0748-0814}




\title{
THE JOURNAL OF LAW AND RELIGION
}

VOLUME XV

2000-2001

NUMBERS $1 \& 2$

EDITORIAL STAFF

Editor

MARIE A. FAILINGER, Hamline University School of Law

Managing and Book Editor

HOWARD J. VOGEL, Hamline University School of Law

Associate Editor

PATRICK KEIFERT, Luther Theological Seminary

Book Review Editor

EDWARD MCGLYNN GAFFNEY, JR., Valparaiso University School of Law

Technical Editor

STEPHEN LIEBO, Hamline University School of Law

Guest Editor

Azizah Y. al-Hibri

Guest Technical Editor

Afra Jalabi

Production/Subscription Manager

LINDA BERGLIN

Student Associate Editor

JULIE C. TESSIER

KEVIN CHANG

ULISSE GALLO

AAISHAH HASHM!

\author{
Editorial Assistants \\ FALLON KELLY \\ NAOMI LIEBO \\ SHARI SELANDER
}

ChRISTA TURNELL

DORETHA WOOTEN

\section{EDITORIAL BOARD}

THOMAS PORTER, Attorney at Law, Boston, Massachusetts, Chair AZIZAH AL-HIBRI, T.C. Williams School of Law, University of Richmond

EDWIN J. BUTTERFOSS, Hamline University School of Law

STEPHEN L. CARTER, Yale Law School

MARIE FAILINGER, Hamline University School of Law

EDWARD MCGLYNN GAFFNEY, JR., Valparaiso University School of Law

EMILY HARTIGAN, Saint Mary's University of San Antonio School of Law

PATRCK KEIFERT, Luther Theological Seminary

HOWARD LESNICK, University of Pennsylvania Law School

ELIZABETH MENSCH, State University of New York at Buffalo, School of Law 
NANCYMILLER-HERRON, Attorney at Law, Dresden, Tennessee

MICHAEL J. PERRY, Wake Forest University School of Law EARL SCHWARTZ, Hamline University

DOUGLAS STURM, Professor Emeritus, Bucknell University

HOWARD J. VOGEL, Hamline University School of Law

ROBERT YAZZIE, Office of the Chief Justice - Navajo Nation 


\section{ADVISORY COMMITTEE}

MILTON KONVITZ, Professor Emeritus, Cornell University of New York, Co-chair DOUGLAS STURM, Professor Emeritus, Bucknell University, Co-chair

TAHA JABER AL-ALWANI, The Graduate School of Social and Islamic Sciences

ZAFAR ISHAQ ANSARI, The International Institute of Islamic Thought

M. SALEEM EL-AWA, Cairo, Egypt

RICHARD BAEPLER, Valparaiso University School of Law

MILNER BALL, University of Georgia School of Law

HAROLD BERMAN, Emory University School of Law

GERARD BRADLEY, Notre Dame University Law School

JAMES BRESNAHAN, Northwestern University Medical School

MICHAEL BROYD, Emory University School of Law

LYNN BUZZARD, Campbell University School of Law

FRED CARNEY, Perkins School of Theology, Southern Methodist University

CARL ESBECK, University of Missouri-Columbia School of Law

RICHARD HIERS, University of Florida

M. CATHLEEN KAVENY, Notre Dame University Law School

DAMIEN KEOWN, University of London, Goldsmiths

SANFORD LEVINSON, University of Texas School of Law

DAVID LITTLE, Harvard University Divinity School

RoBIN LoVIN, Perkins School of Theology, Southern Methodist University

SEYYED HUSSEIN NASR, George Washington University

LoUIS NEWMAN, Carleton College

KAY PRANIS, MN Department of Correction, Restorative Justice

MICHAEL SCHERSCHLIGT, Hamline University School of Law

ELIZABETH SCHUESSLER-FIORENZA, Harvard University Divinity School

THOMAS SHAFFER, Notre Dame University Law School

PETER N. THOMPSON, Hamline University School of Law

CharLes VILLA-VICENCIO, University of Cape Town, South Africa

RosalIE WAHL, Associate Justice, Retired, Minnesota Supreme Court

MICHAEL WELKER, University of Heidelberg, Germany

JOHN WITTE, Jr., Emory University School of Law

WILSON YATES, United Theological Seminary of the Twin Cities

STEPHEN B. YounG, Attorney at Law, Saint Paul, Minnesota 
The Journal of Law and Religion is sponsored by the Hamline University School of Law and is a nonprofit, nonpartisan publication devoted to investigating the interaction of religion and law.

Subscriptions to The Journal of Law and Religion, which is published twice annually, are $\$ 25$ per two-issue volume for individuals, $\$ 35$ for institutions, and $\$ 10$ for students (beginning with Volume XVII). Add an additional $\$ 10$ for foreign postage. Subscription requests, manuscripts, book reviews, books to be reviewed, and general correspondence should be addressed to:

\author{
The Journal of Law and Religion \\ 1536 Hewitt Avenue \\ Saint Paul, Minnesota 55104 \\ or jlr@gw.hamline.edu
}

Commencing with Volume XV, citations conform to the Association of Legal Writing Directors' ALWD Citation Manual. Unsolicited manuscripts will be returned only upon request.

Individual and back issues and complete sets of The Journal of Law and Religion may be ordered directly from William S. Hein \& Co., 1285 Main Street, Buffalo, New York 14209.

The views and opinions expressed in The Journal of Law and Religion are those of the authors and do not necessarily reflect the views of the editorial staff, the editorial board, the advisory board, or the sponsors of The Journal of Law and Religion.

Articles are indexed in the Index to Legal Periodicals published by The H.W. Wilson Co. (Bronx, New York), and in the Legal Resource Index available on-line on a variety of computer database services.

Articles are also indexed in Religion Index One: Periodicals; book reviews are indexed in Index to Book Reviews in Religion. Both indexes are published by the American Theological Library Association, Chicago, and are available online through BRS Information Technologies (Latham, New York) and DIALOG Information Services (Palo Alto, California).

Internet access to The Journal of Law and Religion, including an index to past issues, is available at http://www.hamline.edu/jlr

All copyrights are reserved.

Cite as: 15 J LAW \& RELIG 


\section{JOURNAL OF LAW AND RELIGION}

\section{STATEMENT OF PERSPECTIVE}

The Journal of Law and Religion was initiated in 1982 as a collaborative effort of the Council on Religion and Law and the Hamline University School of Law. It was born of a sense of historical malaise. The modern age with its strong propensity toward the secularization of all areas of life, while not without merit in its liberating effects, nonetheless has its dark side.

We live, some say, in a time of profound historical crisis. Domestically and globally, we confront massive issues which force us to reconsider, in fundamental ways, the shape and quality of our common life. Yet many of the disciplines of thought and practice that should be a rich resource in such a time are found wanting - among them, law and religion. Law, a discipline presumably devoted to the ways of justice, has all too often become a set of complex, technical tools without concem for higher purpose. Religion, presumably given to the all-embracing promises and prescriptions implied in the sense of the sacred, has all too often become privatized and neglectful of our public life.

The Journal of Law and Religion is dedicated to a fundamental reappraisal of the disciplines of law and religion as they impinge on each other, might instruct each other, and taken in their conjunction, might offer a constructive response to the major issues of our times. As such its concems are sixfold.

Historical The Journal intends to encourage the examination of historical developments, movements, thinkers, and issues to enrich our understanding of how law and religion have, in various ways, been mutually influential.

Theoretical The Journal intends to promote constructive work in religious and legal thought about fundamental theological and jurisprudential questions pertaining to professional practice and the structures of our public life.

Ethical The Journal intends to support explorations into the foundations of ethical judgment and normative critiques of our social life, particularly as they draw upon resources from the life of law and religion.

Global The Journal intends to be encompassing in its reach, seeking out voices from all the religious and legal traditions throughout the world and bringing them into conversations with each other.

Professional The Journal intends to stimulate collaboration between jurists and religious leaders given their respective commitments, as professionals, to the common good of all peoples.

Spiritual The Journal recognizes that human existence is grounded in the spiritual, which is represented in many forms and expressions.

The Journal is thus a forum within which the disciplines of law and religion might together consider with utmost seriousness their joint responsibility for the creation of a civilization of genuine peace and justice. Within the compass of that purpose, the Journal intends to be open-minded and non-prejudicial; it is receptive to submissions from all persuasions and perspectives. 


\section{ACKNOWLEDGEMENT}

\section{The Editorial Board of the Journal of}

Law and Religion gratefully acknowledges

the contribution of the Lilly Endowment in

supporting the work of Islamic scholars on

emerging legal issues of concern to the

Muslim community and furthering the

understanding in the non-Muslim world

about this rich tradition of jurisprudence

through its grant to assist in the publication

and worldwide distribution of this issue on

\section{ISLAMIC JURISPRUDENCE.}




\section{Dear Reader,}

With the financial help of the Lilly Endowment, I am very pleased to be able to send you this volume of the Journal of Law and Religion devoted to ISLAMIC JURISPRUDENCE with our compliments. We hope that you will be able to use this volume in your research or work, or will pass it on to someone you know will use it.

Our goal for this volume is to open the fast-growing world of English language Islamic scholarship, especially the work of U.S. scholars, to the entire world, Islamic scholars and public policymakers as well as those who are unfamiliar with the heart of Islamic jurisprudence.

We also hope to encourage more scholarship by emerging as well as well-known Islamic scholars and teachers from diverse perspectives within a common faith.

The Journal of Law and Religion was founded in order to bring scholars and professionals in law and religion back into conversation with each other about the profound crises of our modern world. This conversation is interfaith and interdisciplinary, welcoming persons from all faith traditions including secularists, and all intellectual and scholarly traditions. What we share is the recognition that human existence "is founded in the spiritual" and is essentially ethical, and that serious scholars and professionals can think, write and work on the common good of all peoples out of their faithfulness to their own distinctive traditions. We also share a passion for excellence and critical engagement in important human concerns. If you would like to know more about what the Journal is about or what we have published in past issues, see our website at http://www.hamline.edu/jlr.

We hope that you will join our community of subscribers/readers for the next issues of the Journal. For the modest price of $\$ 25$ for two issues (one volume) per year ( $\$ 35$ for institutional subscribers, and an additional $\$ 10$ per volume for foreign postage), you can become involved in this important dialogue. For a three-year subscription (guaranteed price), we would even be pleased to enter your subscription at a reduced rate $(\$ 60$ for six issues, $\$ 90$ for institutional subscribers, plus foreign postage), or alternatively, send you a complimentary copy of either Volume VIII (the Williamsburg issue) or Volume XVI (our upcoming issue on best books on law and religion published in the 
1990s, and special booklength restorative justice bibliography). For this special offer, please reply by September 30, using the enclosed subcription form.

We look forward to hearing from you.

Marie A. Failinger, Editor 


\section{HAMLINE \\ U N I V E R S I T Y \\ SCHOOL OF LAW}

\section{A subscription to the \\ JOURNAL OF LAW AND \\ RELIGION}

Cost per volume (two issues) beginning with Volume XVII:

$\$ 25.00$ individual (USA)

$\$ 35.00$ individual (foreign)

$\$ 35.00$ institution (USA)

$\$ 45.00$ institution (foreign)

$\$ 10.00$ student

Special 3 Year Rate for 6 issues (valid until 9/30/01):

$\$ 60.00$ individual (USA) $+\$ 30.00$ for foreign

$\$ 90.00$ institution (USA) $+\$ 30.00$ for foreign

Circulation Manager

Journal of Law and Religion

Hamline University School of Law

1536 Hewitt Avenue

Saint Paul, Minnesota 55104

Please include payment with your order.

Name:

Address:

City:

State:

Zip:

Phone:

Fax:

E-Mail: 


\section{ANNOUNCEMENT}

We have acquired the entire back stock, reprint and microform rights to the

\section{JOURNAL OF LAW AND RELIGION}

Complete sets to date are now available. We can also furnish single volumes and issues.

WILLIAM S. HEIN \& COMPANY, INC. 1285 Main Street Buffalo, New York 14209 


\section{THE JOURNAL OF LAW AND RELIGION}

\section{TABLE OF CONTENTS}

\section{Guest Editor's}

Introduction

xxi

\section{ARTICles}

\section{Fatwa}

Taha Jaber al-Alwani Fatwa Concerning the United States Supreme Courtroom Frieze

\section{Selections from Symposium on Women's Rights}

Sandra Day

O'Connor
The Legal Status of Women: The Journey

Toward Equality.

Azizah Yahia al-Hibri Muslim Women's Rights in the Global Village:

Challenges and Opportunities

Ghada G. Qaisi A Student Note: Religious Marriage Contracts: Judicial Enforcement of Mahr

Agreements in American Courts

Non-Violence, Peacebuilding, Conflict Resolution and Human Rights in Islam

Jawdat Said

Law, Religion and the Prophetic Method of Social Change. 
Amr Abdalla

Ebrahim Moosa

Mohammed Abu-

Nimer

David Cole
Principles of Islamic Interpersonal Conflict Intervention: A Search within Islam and Western Literature.

The Dilemma of Islamic Rights Schemes

A Framework for Nonviolence and

Peacebuilding in Islam.

Secrecy, Guilt by Association, and the Terrorist Profile.

\section{ReVIew EsSAYS}

Baudouin Dupret Modern Law and Arab Societies in Recent French-Speaking Literature.

Hilmar Krüger

The Study of Islamic Law in Germany:

A Review of Recent Books on Islamic Law ..... 303

Delfina Serrano Ruano Spanish Research on Islamic Law, 1990-1999

\section{BOOK REVIEWS}

\section{Origins, History and Methodology of Islamic Law}

Mohammad Fadel Analogical Reasoning in Islamic Jurisprudence: A Study of the Juridicial Principle of Qiyas, by Ahmad Hasan

Christopher Melchert On Schacht's "Origins of Muhammadan Jurisprudence, " by M. Mustafa al-Azami; Studies in Early Muslim Jurisprudence, by Norman Calder .363

Harald Motzki The Origins of Islamic Law: The Qur'an, the Muwatta' and Madinan 'Amal, by Yasin Dutton 
Yasin Dutton

Origins of Islamic Jurisprudence,

by Muhammad Yusef Guraya 375

Delfina Serrano Ruano A History of Islamic Legal Theories:

An Introduction to the Sunni Usul Al-Figh, by Wael B. Hallaq

Asifa Quraishi

Principles of Islamic Jurisprudence, by Mohammad Hashim Kamali

Dale F. Eickelman

Shatibi's Philosophy of Islamic Law, by Muhammad Khalid Masud

Birgit Krawietz

The Spirit of Islamic Law,

by Bernard G. Weiss

\section{General Applications of Islamic Law}

D.A. Spellberg

Ingrid Mattson

Nathalie Bernard-

Maugiron

Baudouin Dupret

Adam Sabra

Jonathan Brockopp
The Authoritative and Authoritarian in Islamic Discourses: A Contemporary Case Study, by Khaled Abou El Fadl 397

Al-Ahkam Al-Sultaniyyah: The Laws of Islamic Governance, translated by Asadullah Yate (also translated as) The Ordinances of Government: A Translation of Al-Ahkam Al-Sultaniyya A'Al-Wilayat Al-Diniyya, translated by Wafaa $\mathrm{H}$. Wahba

Islam and Public Law: Classical and Contemporary Studies, edited by Chibli Mallat.

Islamic Law and Culture, 1600-1840, by Haim Gerber

Islamic Law and the State: The Constitutional Jurisprudence of Shihab al-Din al-Qarafi, by Sherman A. Jackson

Islamic Law: Theory and Practice, edited by Robert Gleave \& Eugenia Kermeli....417 
Eugenia Kermeli

Knut S. Vikør

Jöm Thielmann

Jörn Thielmann

Jöm Thielmann

Jörn Thielmann

Jan Goldberg

Richard C. Repp

Ismail Poonawala
Islamic Legal Interpretation: Muftis and their Fatwas, edited by Muhammad Khalid Masud, Brinkley Messick \& David Powers

Law and the Islamic World: Past and Present, edited by Christopher Toll \& Jakob Scovgaard-Petersen

Law as Metaphor: From Islamic Courts to the Palace of Justice, by June Starr

State and Islam, edited by C. van Dijk \& Alexander H. de Groot.

Endowments, Rulers and Community: Wazf al-Haramayn in Ottoman Algiers, by Miriam Hoexter.

Law and Islam in the Middle East, edited by Daisy Hilse Dwyer

Legal Pluralism in the Arab World, edited by Baudouin Dupret, Maurits Berger \& Laila al-Zwaini

State, Society and Law in Islam: Ottoman Law in Comparative Perspective, by Haim Gerber.

\section{Shi'i Jurisprudence}

Crisis and Consolidation in the Formative Period of Shi 'ite Islam: Abu Ja 'far ibn Qiba al-Razi and His Contribution to Imamite Shi' ite Thought, by Hossein Modarressi... 455

M. Saeed Bahmanpour Introduction to Shi' $i$ Law: A Bibliographical Study, by Hossein Modarressi 459 


\section{JOURNAL OF LAW \& RELIGION}

\section{Comparative Religion}

Natana J. De Long-Bas Religion, Law and Society: A Christian-Muslim Discussion, edited by Tarek Mitri

Specific Applications: Commercial Transactions and Financing

Endre Stiansen

A Comparative Evolution of Business

Partnerships: The Islamic World and Europe, with Specific Reference to the Ottoman Archives, by Murat Çizakça

Kamal M. Amjad Mian Islamic Law and Finance; Religion, Risk and Return, by Frank E. Vogel \& Samuel L. Hayes III

Kilian Bälz

Islamic Banking and Interest: A Study of the Prohibition of Riba and its Contemporary Interpretation, by Abdullah Saeed.

\section{Specific Applications: Property and Inheritance}

Tsugitaka Sato

The Islamic Law on Land Tax and Rent: The Peasants' Loss of Property Rights as Interpreted in the Hanafite Literature of the Mamluk and Ottoman Period, by Baber Johansen.

Peter Hennigan

Studies in Qur'an and Hadith: The Formation of the Islamic Law of Inheritance, by David S. Powers

Specific Applications: Family Law and the Role of Women

Knut S. Vikør

Divorce in the Libyan Family: A Study Based on the Sijills of the Shari'ah Courts of Ajdabiyya and Kufra, by Aharon Layish.

Natana J. De Long-Bas Faith and Freedom: Women's Human Rights in the Muslim World, edited by Mahnaz Afkhami 
Natana J. De Long-Bas The Status of Women Under Islamic Law and Under Modern Islamic Legislation, by Jamal J. Nasir

Anna Würth

Sally Cunneen

Amina Wadud

Gisela Webb

Afaf Marsot
Katherine H. Bullock The Veil and the Male Elite: A Feminist

In the House of the Law: Gender and Islamic Law in Ottoman Syria and Palestine, by Judith E. Tucker

In Search of Islamic Feminism: One Woman's Global Journey, by Elizabeth Warnock Fernea

Marriage on Trial: A Study of Islamic

Family Law, by Ziba Mir-Hosseini

Qur'an and Woman: Rereading the Sacred Text from a Woman's Perspective, by Amina Wadud

The Rights of Women in Islam: An Authentic Approach, by Haifaa A. Jawad Interpretation of Women's Rights in Islam, by Fatima Mernissi

Frederick M. Denny Windows of Faith: Muslim Women ScholarActivists in North America, edited by Gisela Webb

Amina Wadud

Servants of Allah: African Muslims Enslaved in the Americas, by Sylviane A. Diouf.

Hina Azam
Chapters on Marriage and Divorce:

Responses of Ibn Hanbal and Ibn Rahwayh, translated by Susan A. Spectorsky; Arab Women: Old Boundaries, New Frontiers, edited by Judith E. Tucker .547 


\section{Specific Applications: Human Rights}

Abdullahi A. An-Na'im Democratization, Liberalization and Human Rights in the Third World; Islamism, Secularism and Human Rights in the Middle East, by Mahmood Monshipouri.....555

Ali Paya Freedom, Modernity and Islam: Towards a Creative Synthesis, by Richard K. Khuri.

Nathalie BernardMaugiron

Human Rights and Democracy: The Role of the Supreme Constitutional Court of Egypt, edited by Kevin Boyle \& Adel Omar Sherif .....567

Baudouin Dupret Islam and Human Rights: Tradition and Politics, by Ann Elizabeth Mayer

\section{Anthropological and Sociological Perspectives in Muslim Communities}

Harold S. Vogelaar Islam in America, by Jane I. Smith .575

Maribel Fierro

Islam in Europe: The Politics of Religion and Community, edited by Steven Vertovec \& Ceri Peach;

Islamic Britain: Religion, Politics and Identity Among British Muslims: Bradford in the 1990s, by Philip Lewis;

Making Muslim Space in North America and Europe, edited by Barbara Daly Metcalf; Muslim Communities in the New Europe, edited by Gerd Nonneman, Tim Niblock \& Bogdan Szajkowski

Natana J. De Long-Bas The Islamization of the Law in Pakistan, by Rubya Mehdi

M.B. Hooker

The Muhimmat al-Nafa'is: A Bilingual Meccan Fatwa Collection for Indonesian Muslims from the End of the Nineteenth Century, by Nico Kaptein 


\section{JOURNAL OF LAW \& RELIGION}

M.N. Farahat

The Rule of Law in the Arab World: Courts in

Egypt and the Gulf, by Nathan J. Brown.

Daniel Price

The Rule of Law in the Arab World: Courts in

Egypt and the Gulf, by Nathan J. Brown

The Myth of the "Islamic Threat to the West; Religion and Politics in the Middle East"

Ali Ahmad

The Future of Islam and the West: Clash of Civilizations or Peaceful Coexistence?, by Shireen T. Hunter

Muriel Paradelle

Islam and the Myth of Confrontation: Religion and Politics in the Middle East, by Fred Halliday

Jörn Thielmann

Islam and Politics, by John L. Esposito

Farish A. Noor

Islam in an Era of Nation States: Politics and Religious Renewal in Muslim South-East Asia, edited by Robert W. Hefner \&

Patricia Horvatich.

Harold S. Vogelaar The Islamic Threat: Myth or Reality?, by John L. Esposito

\section{Source-Criticism and the Biography of Muhammad}

Wim Raven

The Biography of Muhammad: The Issue of the Sources

edited by Harald Motzki 


\section{Journal of Law} \& Religion

http://www.hamline.edu/jlr

Cumulative Index by Subject and Author ๘

Survey of Trends and Developments on Religious Liberty in the Courts

Table of U.S. Supreme Court Decisions

Relating to Religious Liberty

Announcements of Coming Events

Soon to be added:

Article Abstracts of

Past and Current Issues 


\section{transaction publishers}

\section{Books by Milton R. Konvitz}

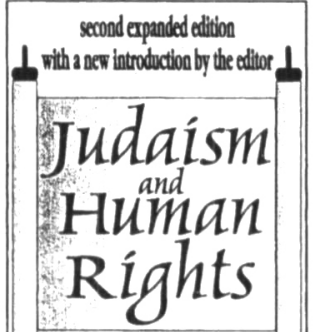

TMilton R. Konniti $T$ editor

\section{Judaism and Human Rights}

Second Expanded Edition

With a new introduction by the editor

A religion or a culture like Judaism, at least three thousand years old, cannot be expected to be all of one piece, homogeneous, self-contained, consistent, a neatly constructed system of ideas. If Judaism were that, it would have died centuries ago and would be a subject of interest only to the historian and archaeologist. Judaism has been a living force precisely because it is a teeming, thundering, and clamoring phenomenon, full of contrary tendencies and inconsistencies. Although there are no words or phrases in Hebrew Scriptures for "human rights," "conscience," or "due process of law," the ideals and values which these concepts represent were inherent in the earliest Jewish texts.

0-7658-0857-9 (paper) 2001442 pp. \$29.95 / £22.95

\section{Fundamental Rights}

History of a Constitutional Doctrine In an illuminating fashion, Konvitz, whose writings have been cited in Supreme Court decisions, traces the controversial and very uneven line of development of "fundamental rights." This volume is likely the first book on the subject and a pioneering work in the history of American constitutional law.

0-7658-0041-1 (cloth) 2000174 pp. \$32.95 / £24.95

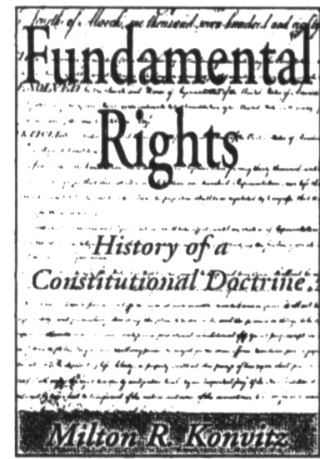

\section{Nine American Jewish Thinkers}

The nine American Jews of whom Milton Konvitz writes are philosophers, jurists, or rabbis, widely known and readily accepted as American Jewish thinkers. Their work reflects all essential Jewish values. Each person in his own way has dedicated his work to the betterment of life and the advancement of human ideals. Although the book is about serious subjects, its graceful style makes the contents easily accessible to lay persons as well as scholars and students of Judaica.

0-7658-0028-4 (cloth) 2000132 pp. \$29.95 / £22.95

Milton R. Konvitz

Visit Our Website

For Online Specials*

www.transactionpub.com

h.

*individual credit card orders only.

Order from your bookstore or direct from the publisher.

Toll free (US only) 1-888-999-6778 or fax 732-748-980

\section{transaction publishers}

Rutgers-The State University of New Jersey Department AD2001 MK01

35 Berrue Circle

Piscataway, NJ 08854-8042

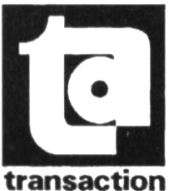

In the U.K. and Europe call: Transaction Publishers (UK) 3 Henrietta Street

Covent Garden

London WC2E BLU

Tel: +44 (0) 2072400856 or fax: +44 (0) 2073790609

In Australia:

Footprint Books Pty Ltd. Unit 4 / $92 A$ Mona Vale Rd.

Mona Vale, NSW 2103

Sydney, NSW 2105

Australia

Tel: 610299973973

Fax: 610299973185 